\title{
INBREEDING DEPRESSION AND GENETIC VARIABILITY IN NELLORE BREED
}

\author{
(Depressão por endogamia e variabilidade genética na raça Nelore)
}

\author{
Rosimira dos Santos Amaral ${ }^{1}$, Carlos Henrique Mendes Malhado ${ }^{2}$, Raimundo Martins Filho ${ }^{3}$, Ana \\ Claudia Mendes Malhado ${ }^{4}$, Marcos Paulo Gonçalves Rezende ${ }^{5}$, Diego Pagung Ambrosini ${ }^{6}$, Paulo \\ Luis Souza Carneiro ${ }^{2}$ \\ ${ }^{1}$ Instituto Federal de Educação, Ciência e Tecnologia Baiano, Campus de Guanambi; ${ }^{2}$ Universidade \\ Estadual do Sudoeste da Bahía; ${ }^{3}$ Universidade Federal do Cariri; ${ }^{4}$ Universidade Fedral de Algoas; \\ ${ }^{5}$ Universidade Estadual do Sudoeste da Bahia, Departamento Pós graduação em Zootecnia; \\ ${ }^{6}$ Instituto Federal de Educação, Ciência e Tecnologia do Amapá;
}

Corresponding author: rosimira.amaral@ifbaiano.edu.br

\begin{abstract}
Inbreeding depression is caused by breeding between closely related individuals and can have a significant negative impact on cattle production. It can be estimated at the population level using pedigree analysis or molecular markers. Such estimations can then be used to better manage the genetic resources of herds. The objective of this study was to evaluate genetic variability and the influence of inbreeding depression on productive traits in 45785 animals Nellore cattle (polled variety) from Brazil. Inbreeding depression was determined by fitting four regression models (linear, quadratic, exponential and Michaelis-Menten) to the errors generated by the animal model. The traits studied were weight at 205 (W205), 365 (W365) and 550 (W550) days of age. The effective number of founders (fe) and ancestors (fa) was 288 and 283, respectively, with 173 ancestors explaining $50 \%$ of the genetic variability in the population. Inbreeding depression effects were identified on all growth traits (W205, W365, and W550), demonstrating significant losses in evaluated weight means. For each $1 \%$ increase in inbreeding there was a depression of about $0.14 \%$ or $0.24 \mathrm{~kg}$ (W205), $0.12 \%$ or $0.29 \mathrm{~kg}$ (W365) and $0.09 \%$ or $0.29 \mathrm{~kg}$ (W550). Exponential and Michaelis-Menten models were similarly efficient predictors for all the traits $(P<0.01)$. We conclude that Nellore cattle in Northeastern Brazil presents low genetic variation and the relationship between inbreeding and depressed productivity in this breed is not linear, with the greatest effects occurring when endogamy is above $20 \%$. To change this scenario, it is important to use a high number of male breeders, mainly young individuals of high breeding value, and improvement of reproductive indexes of females. To achieve this goal, a traditional mating system focused on the utilization of a few (and famous) male breeders should be avoided by both farmers and technicians.
\end{abstract}

Keywords: Bos taurus indicus; genetic diversity; pedigree analysis; population structure; weights.

RESUMO: A depressão por endogamia é causada pelo cruzamento entre indivíduos aparentados e isso pode ter um impacto significativo na produção de gado. A endogamia pode ser estimada em nível populacional usando análise de pedigree. Tais estimativas podem ser usadas para melhorar os recursos genéticos dos rebanhos. O objetivo deste estudo foi avaliar a variabilidade genética e a influência da endogamia sobre bovinos Nelore criados no Brasil. A depressão por endogamia foi determinada pelo ajuste de quatro modelos (linear, quadrático, exponencial e Michaelis-Menten) com base nos erros gerados pelo modelo animal. Foi estudado os pesos ajustados para 205 (P205), 365 (P365) e 550 (P550) dias de 
idade. O número efetivo de fundadores (fe) e ancestrais (fa) foi 288 e 283, respectivamente, com 173 ancestrais explicando $50 \%$ da variabilidade genética na população. Efeitos de depressão por endogamia foram identificados em todas as características de crescimento (P205, P365 e P550), demonstrando perdas significativas nas médias ponderais avaliadas. Para cada aumento de $1 \%$ na endogamia houve uma depressão de cerca de $0,14 \%$ ou $0,24 \mathrm{~kg}$ (P205), 0,12\% ou $0,29 \mathrm{~kg}$ (P365) e 0,09\% ou 0,29 kg (P550). Os modelos exponencial e de MichaelisMenten foram preditores igualmente eficientes para todas as características ( $P$ $<0,01)$. Conclui-se que bovinos da raça Nelore no Nordeste do Brasil apresentam baixa variação genética e que a relação entre endogamia e produtividade deprimida nesta raça não é linear, com os maiores efeitos ocorrendo quando a endogamia está acima de $20 \%$. Para mudar este cenário, é fundamental usar maior quantidade de reprodutores, principalmente com altos valores genéticos para melhorias nos indices reprodutivos das fêmeas. Para atingir este objetivo, um sistema de acasalamento tradicional deve ser evitado tanto pelos pecuaristas quanto por técnicos.

Palavras-chave: Bos taurus indicus; diversidade genética; análise de pedigree; estrutura populacional; pesos. 


\section{INTRODUCTION}

An assessment of the within population genetic variability is necessary for the implementation of effective selection programs and to establish appropriate regimes for the management of genetic resources of herds (Danchin-Burge et al.,, 2012; Malhado et al., 2012). The mating of relatives results in inbreeding depression and a decrease in individual reproductive performance (Wall et al., 2005; Malhado et al., 2013) and productive traits (McParland et al., 2008; Santana Jr et al., 2012; Dai et al., 2015). Inbreeding is an undesirable byproduct of some cattle breeding programs, increasing the frequency of undesirable deleterious genes leading to reproductive problems and reduced production. There are two genetically distinct ways in which increasing homozygosity may reduce performance: i) the expression of harmful recessive mutations, and; ii) an increase in homozygous alleles in loci with heterozygous advantage (Charlesworth and Willis, 2009).

Inbreeding depression may be characterized and quantified as the reduction of a phenotypic trait mean value, frequently productive and reproductive ability (McParland et al., 2009; Charlesworth and Willis, 2009; Lopes et al., 2016; Dotta et al., 2019). Body growth may also be negatively influenced, with a few or no effect on carcass features, such as changes in the feed gain ratio (Carrillo and Siewerdt, 2010). As inbreeding depression is caused by unfavorable combinations of genes it occurs in traits influenced by non additive genetic effects. In small populations, inbreeding coefficients increase quickly, potentially outstripping the ability of selection to increase the frequency of favorable alleles. Research is needed to examine bivariate impacts of selection intensity and inbreeding depression interaction, particularly when different traits (e.g. reproduction and growth) are being effected (Muir, 2000).

In general, the use of residues is justified by the fact that it contains nonadditive effects. The estimated genetic values via usually mixed models only have the additive effect (it does not have the effects of interactions, these go to the residue). The non-additive effects that help explain heterosis are the opposite of inbreeding. So the idea is that by using waste (non-additive effects) we will have a better idea of depression.

Some traits directly associated with performance show significant inbreeding depression, indicating directional dominance and, possibly, epistasis. Carrillo and Siewerdt (2010) recently proposed a methodology in which inbreeding depression on traits is evaluated in relation to the observed values (phenotypic traits) corrected to the fixed effects and additive genetic values, allowing evaluation of the depression in relation to non additive genetic effects. Such methodology has not yet been applied to Brazilian Zebu and thus, to the aim of this study was to evaluate the inbreeding depression assessed through four regression models and population structure of Nellore breed (polled variety), in order to inform rational use of genetic diversity in this breed.

\section{MATERIALS AND METHODS}

Population structure analysis was performed on records of Nellore cattle, polled variety from the Brazilian Association of Zebu Breeders (ABCZ in Portuguese). Data records constituted 45,785 observations between 1960 and 2009. Inbreeding effects were analyzed for adjusted weights at 205 (W205), 365 (W365) and 550 (W550) days of age. In 
contemporary groups (CG), season and year of birth, and herd were used as grouping variables.

The ENDOG 4.8. software (Gutiérrez and Goyache, 2005) was used for pedigree analysis and population parameters estimates by gene origin probability. Inbreeding coefficients $(F)$ were calculated with the algorithm proposed by Meuwissen and Luo (1992). The equivalent number of full generations is obtained by the sum of the $(1 / 2)^{n}$ terms of all known ancestors, in which $n$, is the number of generations that separates the individual from each known ancestor. The mean generation interval was calculated by the four gametic pathways: sire-son, siredaughter, dam-son and dam-daughter.

The effective number of founder animals $\left(f_{e}\right)$ and effective number of ancestor animals $\left(f_{a}\right)$ were used to characterize the genetic diversity the Nellore breed (polled variety). The effective number of founders represents the number of equally contributing founders that would be expected to produce the same genetic diversity as found in the studied population (Boichard et al., 1997). The classic approximation for the determination of effective number of founders was given by:

$$
t_{t}=\frac{1}{\sum_{\zeta-2}^{+} \dot{4}_{k}^{2}} \quad 1
$$

In which:

$t_{:}=$effective number of founders;

$q_{k}=$ allele probability of being originated from the $k$ founder,

The effective number of ancestors represents the minimum number of animals 120 (founders or not) needed to explain the total genetic diversity of the study population.

The effective number of ancestors was determined by computing the marginal using:

$$
f_{L}=\frac{1}{\sum_{i-1}^{g} a \frac{2}{i}} \quad \|
$$

In which:

$f_{a}=$ effective number of ancestors;

$q_{j}=$ marginal contribution of an ancestor $j$ (not exactly a founder), in other words, the genetic contribution that is not explained by an ancestor chosen previously.

The estimation of variance components and prediction of genetic values was performed through univariate analysis (as described by Boldman et al., 1995) using the MTDFREML (Multiple Traits Derivate Free Restrict Maximum Likelihood) application. W205 and W365 have been considered a maternal effect. Thus, for W550 not has used a maternal effect. In general, The model for W205, W365 and W550 was:

$$
y=X \beta+Z_{i a}+Z_{2, n}+Z_{3, s}+c \quad \text { III }
$$

In which:

$y$ is a vector representing the phenotypic observations of a trait;

$\beta$ is a vector of fixed effects (contemporary groups); $a$ is a vector of additive genetic random effects;

$m$ is a vector of maternal genetic effects;

$p$ is a vector of permanent environmental maternal effects;

and $X_{1}, Z_{1}, Z_{2}$ e $Z_{3}$ are design and incidence matrices that relate each observation to the corresponding levels and values of its fixed and random effects.

Random errors were assumed to be independent and have normal distribution $\left(0, \sigma_{e}^{2}\right)$, admitting the covariance between the direct and maternal genetic effects equal to zero. Reports that other studies with the Nellore breed also included a maternal effect on the W365 (Biffani et al., 1999; Ribeiro et al., 2001).

The effect of inbreeding on the traits was determined by fitting four regression models about the errors generated by the animal model (Carrillo 
and Siewerdt, 2010). The general form of these analyses for growth traits was: $e_{i}=q\left(F_{1}\right)+\varepsilon$, where $e_{i}$ are the estimated errors in the vector $\mathfrak{e}=y-X \beta-Z_{1} a-Z_{2} m-Z_{3} c . \mathrm{t}\left(F_{1}\right)$ is a given regression function on the inbreeding coefficient of the animal ( $\left.s_{x}\right)$ and $\varepsilon_{i}$ are the deviations of the errors from the predicted ones in the regression function. The regression models studied were:

Linear

$$
\iota_{i}=\beta_{\mathrm{L}}+\beta_{1}\left(r_{1}-\bar{F}\right)+\varepsilon_{i} \quad \text { IV }
$$

Quadratic

$\mathfrak{c}_{i}=\beta_{\mathrm{i}}+\beta_{1}\left(r_{1}-\bar{F}\right)+\beta_{2}\left(F_{1}-\bar{F}\right)^{2}+\varepsilon_{i} \mathrm{~V}$

Exponential

$$
e_{i}=\alpha \beta^{r i}+\varepsilon_{i} \quad \mathrm{VI}
$$

Michaelis-Menten

$$
\mathrm{c}_{i}=\frac{\hat{\beta}_{2}\left(1-r_{i}\right)}{\left.\vec{p}_{2}-i-r_{i}\right)}+\varepsilon_{1} \quad \text { VII }
$$

Hypothesis tests were conducted for the critical parameters of each regression model, namelyH0: $\beta 1=0$ (linear), $\mathrm{HO}: \beta 2=0$ (quadratic), $\mathrm{HO}: \beta=1$ (exponential) and $\mathrm{HO}$ : $\beta 2=0$ (MichaelisMenten).

In general, in summary form: we initially evaluate population parameters using the ENDOG; we later analyzed the genetic parameters in the MTDFREML for the characteristics; we make a restriction on the ENDOG file for a known minimum generation number; Has imported this results of CG solutions, permanent cow's environment effects and additive effects for new files folder; we construct a new file making a merge of all the files and more the file that contains the results of endogamy; We construct the (error) formula for each trait in the SAS according to the solutions; Finally, we analyze the regression models (linear, exponential, etc.).

\section{RESULTS}

The generation interval estimates of the four gametic pathways (sire-son, sire-daughter, dam-son and damdaughter) were $7.6 \pm 3.6 ; 7.8 \pm 3.6 ; 7.2$ \pm 4.4 and $7.2 \pm 3.8$ years, respectively, with interval average equal $7.5 \pm 3.7$ years mean interval. Mean inbreeding coefficient (F) estimated in six generations showed an increasing trend, exceeding $0.07 \%$ in the second generation and reaching $1.44 \%$ by the sixth generation. Inbred individual percentage also increased from $0.44 \%$ in the second generation to the $26.72 \%$ in the final generation. However, mean $\mathrm{F}$ for inbred animals decreased from the $16.49 \%$ in the second generation to $5.38 \%$ in the sixth generation.

Out of 45,785 animals, 10,618 had at least one unknown parent. Thus, the reference population in which both of the parents are known contained 35,011 individuals. The number of animals with both parent's unknown was only 157 . The effective number of founder herds (the effective number of herds that produce parents, grandparents, greatgrandparents and great-great-greatgrandparents) was only 14 . Founders effective number $\left(f_{e}\right)$ was 288 , ancestors effective number $\left(f_{a}\right)$ was 283 , and the $f_{e}$ I $f_{a}$ reason was 1.02. The expected increase in inbreeding caused by the unbalanced contribution of founders was $0.10 \%$, but 10,292 founders were identified. Only 173 ancestors were necessary (whether founders or not) to explain $50 \%$ of population genetic diversity.

In total, 45,189 individuals had no value for the inbreeding coefficient, 378 had values between $1 \%$ and $10 \%, 127$ individuals had values between $11 \%$ and $12.9 \%$, and 91 individuals had higher values - the highest recorded value was $31.4 \%$ for two animals (Table 1 ). 
Table 1 - Descriptive statistics of the inbreeding coefficient (F) for all population of animals.

\begin{tabular}{cccc}
\hline \multicolumn{2}{c}{$\begin{array}{c}\text { Inbreeding } \\
\text { coefficient }\end{array}$} & $\begin{array}{c}\text { Class of } \\
\text { inbreeding }\end{array}$ & $\begin{array}{c}\text { Number of } \\
\text { animals }\end{array}$ \\
\hline$\leq-$ & 0.009 & 0 & 45234 \\
$0.01-0.029$ & 2 & 60 \\
$0.03-0.049$ & 4 & 103 \\
$0.05-0.069$ & 6 & 152 \\
$0.07-0.089$ & 8 & 7 \\
$0.09-$ & 0.109 & 10 & 11 \\
$0.11-0.129$ & 12 & 127 \\
$0.13-0.149$ & 14 & 22 \\
$0.15-$ & 0.189 & 18 & 10 \\
$0.19-$ & $\geq$ & 31 & 59 \\
\hline
\end{tabular}

From 1984, the first inbred animals appear in the population-based on the best knowledge of the pedigree (0.6 equivalent generations). At this time the mean value of the inbreeding coefficient was close to $0.04 \%$ and remained stable until 1992. After this date, the coefficient increased rapidly until 2002 at which time it reached $0.28 \%$ (1.7 equivalent generations). This value remained relatively stable until 2006 , after which it increased again reaching $1.3 \% \quad(2.2$ equivalent generations) in 2007. The population means $(F)$, considering only the animals with at least 1.5 equivalent generations (20,748 individuals), was $0.25 \%$. Put another way, $F$ for inbred animals (596 individuals) was $9 \%$ (with a mean of 2.8 equivalent generations). From the 596 inbred animals found in the Northeastern Brazil population, only 58 individuals had inbreeding higher than $20 \%$. For the production traits, linear models, exponential and Michaelis-Menten were significant $(P<0.05)$ - except for the linear model for the W550 trait (Table 2).

Linear and exponential models had a similar behavior for W205 and W365 (Figure 1).
Table 2 - Estimate of the inbreeding regression coefficients on weight at 205 (W205), 365 (W365) and 550 days of age (W550) in cattle Nellore, polled variety form northeast Brazil.

\begin{tabular}{lccc}
\hline & \multicolumn{2}{c}{ Models } \\
\cline { 2 - 4 } Traits & Linear & Exponential & $\begin{array}{c}\text { Michaelis- } \\
\text { Menten }\end{array}$ \\
\hline W205 & $\beta=-24.3^{*}$ & $\beta=0.87^{* * *}$ & $\beta_{2}=0.133^{* * *}$ \\
W365 & $\beta=-30.3^{* *}$ & $\beta=0.88^{* * *}$ & $\beta_{2}=0.117^{* * *}$ \\
W550 & $\beta=-30.5^{\text {ns }}$ & $\beta=0.91^{* * *}$ & $\beta_{2}=0.087^{* * *}$ \\
\hline ns = not significant, ${ }^{*} P<0.05 ;{ }^{* *} \mathrm{P}<0.01 ;^{* *} \mathrm{P}<0.001$
\end{tabular}

However, the quadratic model was not significant $(P>0.05$ - results not presented). For each $1 \%$ increase in inbreeding there was a depression of about $0.14 \%$ or $0.24 \mathrm{~kg}$ (W205), $0.12 \%$ or $0.29 \mathrm{~kg}$ (W365) and $0.09 \%$ or $0.29 \mathrm{~kg}$ (W550) (Figure 1).

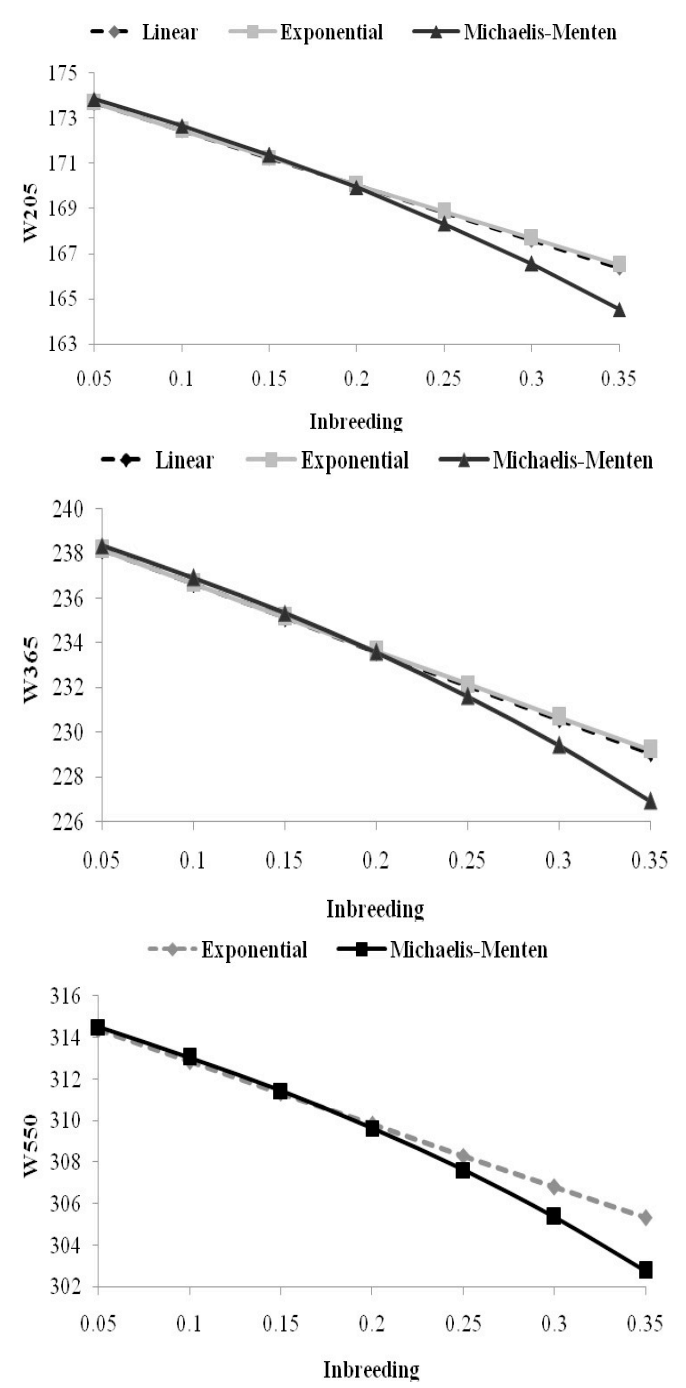

Figure 1 - Inbreeding depression on weight at 205 (W205), 365 (W365) and 550 (W550) days of age of Nellore (polled variety) from Brazil. 


\section{DISCUSSION}

Sire-son and sire-daughter gametic pathways values in Nellore breed, polled variety are lower than those calculated by Faria et al. (2009) for zebu breeds: Nellore (10.7 and 10.5 years), Gyr (9.9 and 9.5 years) and Guzera (10.9 and 10.8 years). Mean sire age by daughter birth was the greatest $(7.8 \pm 3.6$ years $)$ in relation to the other genetic transmission pathways. This could mean that some bulls were repeatedly used, without a faster substitution by their descendents. Such continuous bull use over extended time periods is typically due to the high capital required to acquire such animals, forcing the owner to use such individuals for a long time and to mate them with cows of 'low' genetic quality resulting in 'inferior' offspring. This practice is very common in Brazilian cattle, and is a major cause of generation overlap. Such superposition causes a reversal of expected breeding patterns in which progeny are genetically superior to the parental generation due to efficient artificial selection.

The data suggests that a reduction in generation interval is feasible; mainly sire-son and sire-daughter intervals, which would lead to greater genetic gains by selection. A tool to reduce such interval is the use of (evaluated) young bulls. The broad employment of famous breeders contributes to generation interval increase and family size variation (Faria et al., 2009), which is one of the main factors related to effective population size. Excessively broad intervals reduce annual genetic gain for the selected traits, resulting in a minor economic profit for the breeding program (Reis Filho et al., 2010).

A consistent increase in $F$ and in the percentage inbred animals across generations may be due to the fact that the more generations of an individual is known, the greater the possibility of an important ancestor appearing in the pedigree. A reduction in mean $F$ for inbred animals between second and sixth generation is possibly related to the strategy of avoiding mating by closely related animals. However, the low pedigree integrality highlights that inbreeding may be underestimated in the Nellore herd, polled variety. The lack of information about ancestors, resulting from mating with imported animals was a potential contributing factor in the reduction in inbreeding levels in the 1970's and 1980's in Hereford herds in the United States (Cleveland et al., 2005). This highlights that incomplete pedigrees may provide inaccurate information of inbreeding real value.

The low ancestor number (whether founders or not) explaining $50 \%$ of population genetic diversity is an indicator of the unbalanced use of breeders. Such a situation reflects the low values of the effective number of founders and ancestors. Our results suggest that this population genetic diversity is attributable to only 173 individuals, which is too low for the 10,292 estimated ancestors in the reference population. Maintaining herd variability needs a robust population management program with controlled mating and / or artificial insemination. The effective numbers of founders $\left(f_{e}=\right.$ 288) and ancestors $\left(f_{a}=283\right)$ are very close. When these values are identical it means that the animals that have contributed to the breed / variety formation continue to influence the current herd. Thus, animals considered founders have effectively contributed to the herd composition. The ideal situation is to have high effective numbers of founders, which was not observed in this study since $f_{e}$ and $f_{a}$ are low in comparison to the base $(45,785)$ and reference $(35,011)$ populations. Thus, the Nellore herd, polled variety was developed from a narrow genetic base (a founder effect). Furthermore, the low number of breeders, a prohibition on the 
importation of genetic resources (from 1962), and the preference for determined bulls, may also have contributed to the current genetic diversity in the Polled population.

The observed $f_{a}$ was 283 . This is greater than that reported by Vozzi et al. (2006) for Nellore breed (59.8) and Nellore breed, polled variety (61.5) from the national herd, participating of Nellore Breed Genetic Improvement Program. However, the estimated value of $f_{e}$ (288) in the present work was relatively high in comparison to other breeds and varieties evaluated in Brazil. Mean founders $\left(f_{e}\right)$ and ancestors $\left(f_{a}\right)$ numbers are slightly different, giving an $f_{e} / f_{a}$ ratio of 1.02. This value is lower than that obtained by Faria et al. (2009) for Nellore breed (1.12). The $f_{e} / f_{a}$ ratio indicates the "bottleneck" effect on pedigree and is influenced by the reduction in the number of breeders used. Zebu breeds in Brazil tended to lose genetic diversity because of the low number of founders and the system of selection for breeding (Panetto et al., 2010).

The total number of individuals in an animal improvement program is usually limited by economic factors. Effective population size mainly depends on fertility and fecundity parameters, as well as selection response predictions. Among all the variables a cattle breeder may manipulate, population size has the greatest range of consequences. In the short-term, this parameter influences the selection differential, inbreeding depression and the reduction of genetic variance due to genetic drift. In the longterm it affects the selection limit and the availability of new variation due to mutation (Toro and Pérez-Encisco, 1990).

During the early years of the study values above zero for mean inbreeding were observed. This was probably caused by a period of herd formation in which much pedigree information may have been lost, thereby precluding kinship establishment. Inbreeding coefficients from 1984 considerably increased. Most zebu breeds in Brazil have a very low effective population size which may result in high inbreeding in the future (Faria et al., 2009). Actions for genetic variation maintenance, together with genetic improvement, may be needed to maintain selection response in a long-term and to avoid the undesirable effects of inbreeding. Faria et al. (2009) reported increasing inbreeding levels in Nellore, Gyr and Guzerat breeds in Brazil, reaching values as $2.13 \%, 2.28 \%$ and $1.75 \%$, respectively. Likewise, Cleveland et al. (2005) observed an increase in inbreeding in Hereford herds in the U.S.A., although levels observed were lower than critical values.

The quadratic model is usually taken as the first choice in cattle inbreeding studies (Carolino and Gama, 2008). However, this model was inadequate to detect inbreeding effects in all three evaluated traits $(P>0.05)$. Thus, in this case the exponential model was superior. The increase in inbreeding caused a reduction in the three growth traits (W205, W365 and W550). Carrillo and Siewerdt (2010) estimated some values close to the ones of the present study for W205 trait in Angus breed $(\beta=$ 25.28, $\beta=0.897$ and $\beta_{2}=0.10$, for linear, exponential and Michaelis-Menten models, respectively).

Exponential and Michaelis-Menten models were similarly efficient predictors for all the traits $(P<0.01)$. Similar results were found by Carrillo and Siewerdt (2010) evaluating long-term inbreeding accumulation consequences over weaning traits in a closed Angus herd. Linear models are simply adjusted, having direct interpretation parameters, but do not have the flexibility and capacity to deal with the linear deviations seen at higher inbreeding values. Carrillo and Siewerdt (2010) 
suggest that the choice between linear or exponential models to describe inbreeding effects must made be on the basis inbreeding value intervals in the data set. Thus, for short ranges which focus on low values of inbreeding, linear model will provide satisfactory approximations. For larger inbreeding intervals or for higher inbreeding levels, exponential models provide more flexibility to deal with non-linearity. For Nellore breed, polled variety in our study (492 individuals), approximately $90 \%$ of the inbred animals had 0.01 to 0.20 inbreeding. Thus, the linear model may be preferential to the exponential in W205 and W365 traits.

For lower inbreeding levels, a linear model thus provides a reasonable approximation. However, a MichaelisMenten model indicated that from 20\% inbreeding there is a greater depression of traits, highlighting the non-linearity of phenomenon. In fact, up to $F=0.20$ depression is approximately linear, and after this there is a greater effect on productive traits (Figure 1). Inbreeding depression is higher when its effects are expressed in adverse environmental conditions. However, breeds created in extensive systems under extreme climatic condition and feeding restrictions often demonstrate intense inbreeding depression (Carolino and Gama, 2008). Cattle genetic management should therefore seek strategies to reduce future inbreeding, whereby it would be possible to notice biological performance reduction or threats to the quality of selection programs (Carrillo and Siewerdt, 2010).

Inbreeding depression detection depends on accurate inbreeding estimates, since the traditionally used coefficient $(F)$ is not linear across generations and may lead to different conclusions about inbreeding depression depending on pedigree depth (Panetto et al., 2010). In a study of Jersey and Holstein cows, it was observed that kinship information (known generations) was associated with the higher detection of inbreeding: 0.04 (with $<31 \%$ of pedigree), 1.65 (from 31 to $70 \%$ ) and 2.06 (from 71 to 100\%) (Cassell et al., 2003). Inbreeding is thought to depress animal performance because individuals with higher homozygosity are less tolerant to environmental stress.

\section{CONCLUSIONS}

Nellore cattle, polled variety in Northeastern Brazil presents high generation intervals and low genetic variation. Inbreeding depression effects were identified on all growth traits (W205, W365 and W550), demonstrating significant losses in evaluated weight means, with greater depression of traits after $20 \%$ inbreeding. To change this scenario, it is important to use a high number of male breeders, mainly young individuals of high breeding value, and improvement of reproductive indexes of females. In addition, the genetic diversity of this population needs to be periodically monitored. To achieve this goal, traditional mating system focused on utilization of a few (and famous) male breeders should be avoided by both farmers and technicians.

\section{REFERENCES}

BIFFANI, S. et al. Environmental and genetic effects on yearling and postyearling weights of Nellore calves in Northeast Brazil. Revista Brasileira de Zootecnia, v.28, p.468-472, 1999.

BOICHARD, D. MAIGNEL, L. VERRIEL, $E$. The value of using probabilities of gene origin to measure genetic variability in a population. Genetics Selection Evolution, v.29, p.5-23, 1997. 
BOLDMAN, K. G. et al. A manual for use of MTDFREML: a set of programs to obtain estimates of variances and covariances [Draft]. ARS, USDA, Washington, DC, 1995.

CAROLINO, N. GAMA, L.T. Inbreeding depression on beef cattle traits: estimates, linearity of effects and heterogeneity among sire-families. Genetics Selection Evolution, v.40, p.511-527, 2008.

CARRILLO, J. A. SIEWERDT, F. Consequences of long-term inbreeding accumulation on preweaning traits in a closed nucleus Angus herd. Journal of Animal Science, v.88, p.87-95, 2010.

CASSELL, B.G.; ADAMEC, V. PEARSON, R.E. Effect of incomplete pedigrees on estimates of inbreeding and inbreeding depression for days to first service and summit milk yield in Holstein and Jerseys. Journal of Dairy Science, v.86, p.2967-2976, 2003.

CHARLESWORTH, D. WILLIS, J. H. The genetics of inbreeding depression. Heredity v.10, p.783- 796, 2009.

CLEVELAND, M. A. et al. Changes in inbreeding of U.S. Herefords during the twentieth century. Journal Animal Science, v.83, p.992-1001, 2005.

DAI, S. et al. Inbreeding and its effects on fleece traits of Inner Mongolia cashmere goats. Small Ruminat Research, v.128, p.50-53, 2015.

DANCHIN-BURGE, C. et al. Evolution of the genetic variability of eight French dairy cattle breeds assessed by pedigree analysis. Journal of Animal Breeding and Genetics, v.129, p.206217, 2012.

DOTA, J.C. et al. Population structure and inbreeding depression on growth traits in Nellore cattle reared in the Amazon Biome. Livestock Research for Rural Development, v.31, p.1-12, 2019.
FARIA, F. J. C. et al. Pedigree analysis in the brazilian zebu breeds. Journal of Animal Breeding and Genetics, v.126, p.148-153, 2009.

GUTIÉRREZ, J. P. GOYACHE, F. A note on ENDOG a computer program for analysing pedigree information. Journal of Animal Breeding and Genetics, v.122, p.172-176, 2005.

LOPES, F. B. et al. Inbreeding effect on pre-weaning weight in polled Nellore cattle raised on pasture in the Cerrado biome. Archivos de Zootecnia, v.65, p.177-182. 2016.

MALHADO, C. H. M. et al. Population structure and genetic variability in the Murrah dair breed of water buffalo in Brazil acessed via pedigree analysis. Tropical Animal Health Production, 2012.

MALHADO, C. H. M. et al. Inbreeding depression on production and reproduction traits of buffaloes from Brazil. Animal Science Journal, v.84, p.289-295, 2013.

MCPARLAND, $S$. et al. Inbreeding effects on postweaning production traits, conformation, and calving performance in Irish beef cattle. Journal of Animal Science, v.86, p.3338-3347, 2008.

MCPARLAND, S.; KEARNEY, J. F. BERRY, D. P. Purging of inbreeding depression within the Irish HolsteinFriesian population. Genetics Selection Evolution, v.41, p.1-8, 2009.

MEUWISSEN, T. H. E. LUO, Z. Computing inbreeding coefficients in large populations. Genetics Selection Evolution, v.24, p.305-313, 1992.

MUIR, W. M. The interaction of selection intensity, inbreeding depression, and randon genetic drift on short and longterm response to selection: Results using finite locus and finite population size models incorporating directional dominance. In: Proceedings of the American Society of Animal Science, 
1992. Retrieved on 01 march 2015 from http://www.journalofanimal science.org/content/79/E-Suppl_1/1.2.

PANETTO, J. C. C. et al. Assessment of inbreeding depression in Guzera dairy herd: effects of individual increase in inbreeding coefficients on production and reproduction. Journal of Dairy Science, v.93, p.4902-4912, 2010.

REIS FILHO, J. C. et al. Population structure of brazilian Gyr dairy cattle. Revista Brasileira de Zootecnia 39, 2640-2645, 2010.

RIBEIRO, M. N. et al. Heritability of Maternal and Direct Effects of Growth Traits in Nellore Herds at Paraiba State, Brazil. Revista Brasileira de Zootecnia, v.30, p.1224-1227, 2001.

SANTANA JR, M. L. et al. Pedigree analysis and inbreeding depression on growth traits in brazilian Marchigiana and Bosnmara breeds. Journal Animal Science, v.90, p.99-108, 2012.

TORO, M. PÉREZ-ENCISO, M. 1990. Optimization of selection response under restricted inbreeding. Genetics Selection Evolution, v.22, p.93-107.

VOZZI, P. A. et al. Structure and genetic diversity in Nellore (Bos indicus) cattle by pedigree analysis. Genetic Molecular Biology, v.29, p.482-485, 2006.

WALL, E. et al. Impact of non additive genetic effects in the estimation of breeding values for fertility and correlated traits. Journal of Dairy Science, v.88, p.376-385, 2005. 